\title{
Pertumbuhan Tanaman Nanas pada Berbagai Konsentrasi IBA Secara In Vitro
}

\section{(The Pineapple Plants Growth at Various IBA Concentration by In Vitro)}

\author{
Zarmiyeni $^{1)}$ \& Siti Munawarah ${ }^{2)}$ \\ Pogram Studi Agroteknologi, Sekolah Tinggi Ilmu Pertanian Amuntai \\ ${ }^{1)}$ zarmiyenilg@yahoo.co.id \\ ${ }^{2)}$ sirwah@gmail.com
}

\begin{abstract}
ABSTRAK
Masyarakat Kabupaten Hulu Sungai Utara sangat menyukai buah nanas, hal ini dapat dilihat dari terus meningkatnya permintaan pasar terhadap buah nanas. Produksi nanas di Kabupaten Hulu Sungai Utara dari tahun 2010-2013 terus meningkat. Namun, ketersediaan buah nanasnya masih banyak dipasok dari daerah lain. Hal ini dikarenakan oleh keterbatasan lahan dan ketersediaan bibit unggul. Oleh karena itu diperlukan suatu teknik baru untuk mengatasi masalah tersebut yaitu dengan perbanyakan secara in vitro. Penelitian ini bertujuan (i) untuk mengetahui respon pertumbuhan tanaman nanas terhadap berbagai konsentrasi IBA (Indole Butyric Acid) secara in vitro dan (ii) untuk mendapatkan konsentrasi IBA (Indole Butyric Acid) terbaik untuk pertumbuhan tanaman nanas secara in vitro. Penelitian yang dilaksanakan di laboratorium kultur jaringan STIPER Amuntai dari bulan Maret Juni 2014, menggunakan Rancangan Acak Lengkap (RAL) dengan 5 taraf perlakuan, 4 kali ulangan. Faktor yang diuji adalah konsentrasi IBA, yaitu $i_{1}=1,5 \mathrm{ppm}, i_{2}=2 \mathrm{ppm}, i_{3}=2,5 \mathrm{ppm}, i_{4}=3 \mathrm{ppm}$, dan $i_{5}$ = 3,5 ppm. Hasil penelitian menunjukkan belum diketahui respon dan konsentrasi terbaik IBA terhadap pertumbuhan tanaman nanas.
\end{abstract}

Kata Kunci: Tanaman, buah, nanas, IBA, in vitro.

\section{ABSTRACT}

The people of Hulu Sungai Utara Regency are very fond of pineapple, this can be seen from the continued increase in market demand for pineapple. Pineapple production in Hulu Sungai Utara Regency from 2010-2013 continues to increase. However, the availability of pineapple is still widely supplied from other regions. This is due to limited land and the availability of superior seeds. Therefore we need a new technique to overcome this problem by multiplying it in vitro. This study aims (i) to determine the response of pineapple plant growth to various concentrations of IBA (Indole Butyric Acid) in vitro and (ii) to obtain the best IBA (Indole Butyric Acid) concentration for pineapple plant growth in vitro. The study was conducted in the Amuntai STIPER tissue culture laboratory from March to June 2014, using a Completely Randomized Design (CRD) with 5 treatment levels, 4 replications. The factor tested was the IBA concentration, $i_{1}=1.5 \mathrm{ppm}, i_{2}=2 \mathrm{ppm}, i_{3}=2.5 \mathrm{ppm}, i_{4}=3 \mathrm{ppm}$, and $i_{5}=3.5 \mathrm{ppm}$. The results showed no known response and the best concentration of IBA on pineapple plant growth.

Keywords: Plants, fruit, pineapple, IBA, in vitro.

\section{PENDAHULUAN}

Masyarakat Kabupaten Hulu Sungai Utara sangat menyukai buah nanas, hal ini dapat dilihat dari terus meningkatnya permintaan pasar terhadap buah nanas. Berdasarkan data dari Dinas Pertanian Tanaman Pangan dan Hortikultura Kabupaten Hulu Sungai Utara menyatakan bahwa produksi tanaman nanas dari tahun 2010-2013 terus meningkat yaitu dari 0,2 ton menjadi 2,7 ton. Menurut Rukmana (1996), bagian utama yang bernilai ekonomi dari tanaman nanas adalah buahnya. Buah nanas selain dikonsumsi segar juga dapat diolah menjadi berbagai produk makanan dan minuman, seperti dibuat selai, sari buah, dan lain-lain.

Ketersediaan buah nanas di Kabupaten Hulu Sungai Utara masih banyak dipasok dari daerah lain. Hal ini dikarenakan oleh keterbatasan lahan dan ketersediaan bibit unggul. Oleh karena itu, diperlukan suatu teknik baru untuk mengatasi permasalahan tersebut yaitu dengan perbanyakan secara in vitro. Perbanyakan secara in vitro atau 
kultur jaringan merupakan salah satu teknik perbanyakan tanaman secara vegetatif. Komponen-komponen yang mempengaruhi keberhasilan perbanyakan dengan teknik kultur jaringan salah satunya adalah zat pengatur tumbuh (Kartha, 1981 dalam Zulkarnain, 2011).

Selain ketersediaan lahan, kendala lainnya yang ada di Kabupaten Hulu Sungai Utara untuk budidaya nanas adalah ketersediaan bibit unggul. Bibit yang diperlukan dalam budidaya adalah bibit yang baik kuantitas dan kualitasnya. Menurut Rugayah, et. al., (2012), bibit nanas dapat diperoleh dari perbanyakan secara generatif dan perbanyakan secara vegetatif. Namun, yang sering digunakan adalah perbanyakan dengan cara vegetatif. Perbanyakan tanaman nanas secara vegetatif biasanya menggunakan tunas anakan, slip (tunas dasar buah), tunas mahkota, mahkota, dan stek batang.

Perbanyakan tanaman nanas secara vegetatif seperti stek tunas yang langsung ditanam ke tanah akan menghasilkan jumlah bibit yang sedikit, memerlukan tempat yang luas, waktu yang sangat lama dan tergantung musim. Hal ini akan memperlambat ketersediaan buah nanas. Oleh karena itu, diperlukan suatu teknik baru untuk mengatasi permasalahan tersebut yaitu dengan perbanyakan secara in vitro. Perbanyakan secara in vitro atau kultur jaringan merupakan salah satu teknik perbanyakan tanaman secara vegetatif.

Komponen-komponen

yang mempengaruhi keberhasilan perbanyakan dengan teknik kultur jaringan adalah zat pengatur tumbuh, eksplan, komposisi media, dan stimulus fisik seperti cahaya, suhu, dan kelembaban (Kartha, 1981 dalam Zulkarnain, 2011). Dewi (2008) menyatakan bahwa, zat pengatur tumbuh adalah senyawa organik bukan nutrisi yang dalam konsentrasi rendah $(<1 \mathrm{mM})$ mampu mendorong, menghambat, dan mengubah pertumbuhan dan perkembangan tanaman. Zat pengatur tumbuh yang digunakan untuk merangsang terbentuknya akar pada perbanyakan in vitroadalah auksin (Suprapto, 2004). Auksin yang digunakan adalah IBA.
Penelitian ini bertujuan untuk (i) mengetahui respon pertumbuhan tanaman nanas terhadap berbagai konsentrasi IBA (Indole Butyric Acid) secara in vitro (ii) mendapatkan konsentrasi IBA (Indole Butyric Acid) terbaik untuk pertumbuhan tanaman nanas secara in vitro

\section{METODE PENELITIAN}

Penelitian ini telah dilaksanakan di laboratorium kultur jaringan STIPER Amuntai pada bulan Maret - Juni 2014. Bahan dan Alat yang digunakan adalah mahkota nanas, media MS bassal medium w/ vitamin, agar, gula pasir, zat pengatur tumbuh BAP, zat pengatur tumbuh IBA, fungisida, bakterisida, alkohol $70 \%$, alkohol $96 \%$, klorok $50 \%$, 15\%, dan 10\%, aquadest, sabun cuci piring, deterjen, aluminium foil, spritus, kertas lakmus, $\mathrm{NaOH}$ dan $\mathrm{HCl}$. Alatalat yang akan digunakan dalam penelitian ini adalah Laminar Air Flow Cabinet (LAFC), autoklaf, hotplate magnetik stirrer, kompor gas, botol kultur, oven, erlenmeyer, gelas beker atau gelas piala, petridish (cawan pertri), gelas ukur, pinset, scalpel, sprayer, ruang inkubasi, timbangan analitik ohaus, lampu Bunsen, pipet volume, pipet tetes, pengaduk, karet gelang, termometer bola basah bola kering, sikat botol, kamera, dan alat tulis.

\section{Rancangan Penelitian}

Penelitian ini merupakan percobaan yang dilakukan di dalam ruang terkontrol dan rancangan percobaan yang dilakukan adalah rancangan acak lengkap (RAL) faktor tunggal. Perlakuan (treatment) yang digunakan adalah konsentrasi IBA (i) yang terdiri dari 5 taraf yaitu: $\mathrm{i}_{1}=1,5 \mathrm{ppm}, \mathrm{i}_{2}=2$ ppm, $i_{3}=2,5 \mathrm{ppm}, \mathrm{i}_{4}=3 \mathrm{ppm}, \mathrm{i}_{5}=3,5 \mathrm{ppm}$. Masing-masing perlakuan diulang 4 kali ulangan, sehingga diperoleh 20 satuan percobaan dan setiap satuan percobaan terdiri dari 4 eksplan sebagai sampel.

\section{Pelaksanaan Penelitian}

Pelaksanaan penelitian meliputi persiapan, pembersihan laboratorium 
persiapan alat pembuatan media, pemberian perlakuan, persiapan eksplan, penanaman eksplan, pemeliharaan, pengamatan

Peubah yang diamati pada penelitian ini adalah sebagai berikut:

Persentase tumbuh (\%). Persentase tumbuh tanamaan diamati pada 14, 28, dan 42 HST. Persentase tumbuh diamati dengan menghitung jumlah eksplan yang hidup dengan cara sebagai berikut:

$$
\frac{\text { jumlah eksplan yang hidup }}{\text { jumlah eksplan yang ditanam }} \times 100 \%
$$

Persentase eksplan bertunas (\%). Persentase eksplan bertunas pada tanaman diamati pada 21, 35, dan 49 HST. Persentase eksplan bertunas diamati dengan menghitung jumlah tunas yang terbentuk pada setiap eksplan dengan cara sebagai berikut:

$$
\frac{\text { jumlah eksplan yang bertunas }}{\text { jumlah eksplan yang ditanam }} \times 100 \%
$$

Persentase eksplan berakar (\%). Persentase eksplan berakar pada tanaman diamati pada 21,35 , dan 49 HST. Persentase eksplan berakar diamati dengan cara sebagai berikut:

$$
\frac{\text { jumlah eksplan yang berakar }}{\text { jumlah eksplan yang ditanam }} \times 100 \%
$$

Jumlah akar (buah). Jumlah akar diamati dengan cara menghitung akar yang terbentuk pada satu eksplan. Pengamatan jumlah akar dilakukan pada akhir penelitian (49 HST).

Jumlah daun (buah). Jumlah daun diamati dengan cara menghitung daun yang terbentuk nomal. Pengamatan jumlah daun dilakukan pada akhir penelitian (49 HST).

\section{HASIL DAN PEMBAHASAN}

Hasil
Persentase Tumbuh (\%)
Persentase tumbuh tanaman nanas
diamati pada umur 14, 28, dan 42 HST. Data
pengamatan tidak dapat dianalisis
menggunakan analisis sidik ragam, sehingga
hanya diinterpretasi data.Rata-rata
persentase tumbuh disajikan pada Tabel 1.

Tabel 1. Rata-rata persentase tumbuh tanaman nanas

\begin{tabular}{cccc}
\hline \multirow{2}{*}{ Perlakuan } & \multicolumn{3}{c}{ Rata-rata persentase tumbuh $(\%)$} \\
\cline { 2 - 4 } & $14 \mathrm{HST}$ & $28 \mathrm{HST}$ & $42 \mathrm{HST}$ \\
\hline $\mathrm{i}_{1}(1,5 \mathrm{ppm})$ & 25 & - & - \\
\hline $\mathrm{i}_{2}(2 \mathrm{ppm})$ & - & - & - \\
\hline $\mathrm{i}_{3}(2,5 \mathrm{ppm})$ & 37,5 & 25 & - \\
\hline $\mathrm{i}_{4}(3 \mathrm{ppm})$ & 43,75 & 12,5 & 12,5 \\
\hline $\mathrm{i}_{5}(3,5 \mathrm{ppm})$ & 25 & 18,75 &
\end{tabular}

Keterangan: data tidak diolah karena tidak memenuhi kaidah statistik.

$$
\text { - : mati }
$$

\section{Persentase Terbentuknya Tunas $(\%)$}

Persentase terbentuknya tunas diamati pada umur 21, 35, dan 49 HST. Data pengamatan tidak dapat dianalisis menggunakan analisis sidik ragam, sehingga hanya diinterpretasi data. Rata-rata persentase terbentuknya tunas disajikan pada Tabel 2.

Tabel 2. Rata-rata persentase terbentuknya tunas tanaman nanas. 


\begin{tabular}{cccc}
\cline { 2 - 4 } & $21 \mathrm{HST}$ & $35 \mathrm{HST}$ & $49 \mathrm{HST}$ \\
\hline $\mathrm{i}_{1}(1,5 \mathrm{ppm})$ & - & - & - \\
$\mathrm{i}_{2}(2 \mathrm{ppm})$ & - & - & - \\
$\mathrm{i}_{3}(2,5 \mathrm{ppm})$ & 25 & 25 & 18,75 \\
$\mathrm{i}_{4}(3 \mathrm{ppm})$ & 12,5 & 12,5 & - \\
$\mathrm{i}_{5}(3,5 \mathrm{ppm})$ & 25 & 18,75 & 12,5 \\
\hline
\end{tabular}

Keterangan: data tidak dapat diolah karena tidak memenuhi kaidah statistik

- : mati

\section{Persentase Terbentuknya Akar (\%)}

Persentase terbentuknya akar diamati pada umur 21, 35, dan 49 HST. Data pengamatan tidak dapat dianalisis menggunakan analisis sidik ragam, sehingga hanya diinterpretasi data. Rata-rata persentase terbentuknya akar disajikan pada Tabel 3.

Tabel 3. Rata-rata persentase terbentuknya akar tanaman nanas.

\begin{tabular}{cccc}
\hline Perlakuan & \multicolumn{3}{c}{ Rata-rata persentase terbentuknya akar $(\%)$} \\
\cline { 2 - 4 } & $21 \mathrm{HST}$ & $35 \mathrm{HST}$ & $49 \mathrm{HST}$ \\
\hline $\mathrm{i}_{1}(1,5 \mathrm{ppm})$ & - & - & - \\
$\mathrm{i}_{2}(2 \mathrm{ppm})$ & - & - & - \\
$\mathrm{i}_{3}(2,5 \mathrm{ppm})$ & 0 & 0 & 0 \\
$\mathrm{i}_{4}(3 \mathrm{ppm})$ & 0 & 0 & - \\
$\mathrm{i}_{5}(3,5 \mathrm{ppm})$ & 0 & 0 & 6,25 \\
\hline
\end{tabular}

Keterangan: data tidak diolah karena tidak memenuhi kaidah statistik

$$
\begin{aligned}
& \text { - } \quad \text { mati } \\
& 0 \quad \text { : tidak terbentuk akar }
\end{aligned}
$$

\section{Jumlah Akar (buah)}

Pengamatan jumlah akar dilakukan pada akhir pengamatan yaitu 49 HST. Data pengamatan tidak dapat dianalisis menggunakan analisis sidik ragam, sehingga hanya diinterpretasi data.Rata-rata jumlah akar disajikan pada Tabel 4.

Tabel 4. Rata-rata jumlah akar tanaman nanas.

\begin{tabular}{cc}
\hline Perlakuan & Rata-rata jumlah akar \\
\hline i $_{1}(1,5 \mathrm{ppm})$ & - \\
$\mathrm{i}_{2}(2 \mathrm{ppm})$ & - \\
$\mathrm{i}_{3}(2,5 \mathrm{ppm})$ & 0 \\
$\mathrm{i}_{4}(3 \mathrm{ppm})$ & - \\
$\mathrm{i}_{5}(3,5 \mathrm{ppm})$ & 0,3125 \\
\hline
\end{tabular}

Keterangan: data tidak diolah karena tidak memenuhi kaidah statistik

$$
\begin{aligned}
& \text { - : mati } \\
& 0: \text { tidak terbentuk akar }
\end{aligned}
$$

\section{Jumlah Daun (helai)}

Pengamatan jumlah daun dilakukan pada akhir pengamatan yaitu 49 HST. Data pengamatan tidak dapat dianalisis menggunakan analisis sidik ragam, sehingga 
Zarmiyeni \& Siti Munawarah, Pertumbuhan tanaman nanas..

hanya diinterpretasi data.Rata-rata jumlah daun disajikan pada Tabel 5.

Tabel 5. Rata-rata jumlah daun tanaman nanas

\begin{tabular}{cc}
\hline Perlakuan & Rata-rata jumlah daun \\
\hline $\mathrm{i}_{1}(1,5 \mathrm{ppm})$ & - \\
$\mathrm{i}_{2}(2 \mathrm{ppm})$ & - \\
$\mathrm{i}_{3}(2,5 \mathrm{ppm})$ & 1 \\
$\mathrm{i}_{4}(3 \mathrm{ppm})$ & - \\
$\mathrm{i}_{5}(3,5 \mathrm{ppm})$ & 0,3125 \\
\hline
\end{tabular}

Keterangan: data tidak diolah karena tidak memenuhi kaidah statistik

- : mati

\section{Pembahasan}

Hasil pengamatan persentase tumbuh eksplan nanas menunjukkan bahwa tidak semua eksplan tumbuh.Eksplan mati disebabkan karena terjadinya kontaminasi dan pencoklatan (browning).Kontaminasi ini diduga berasal dari bahan tanam yang kurang baik, lingkungan yang kurang mendukung dan rendahnya tingkat keterampilan peneliti.Jenis kontaminasi disebabkan oleh bakteri dan jamur.Ciri awal terserang bakteri yaitu adanya bercak-bercak putih berlendir dipermukaan media.Sedangkan ciri awal terserang jamur yaitu munculnya benang-benang halus berwarna putih dipermukaan media atau eksplan. Menurut Santoso \& Nursandi (2004), pencoklatan disebabkan karena bahan tanam yang digunakan dalam keadaan tidak normal, media dan suplemen media yang beragam, pengunaan bahan sterilisasi, pengirisan, penggunaan api dan lain-lain. Gejala pencoklatan merupakan tanda-tanda kemunduran fisiologis eksplan dan menyebabkan eksplan mati.

Hasil pengamatan persentase terbentuknya tunas pada eksplan nanas menunjukkan tidak semua eksplan bertunas, karena banyak terdapat eksplan yang mati. Eksplan yang mati disebabkan oleh kotaminassi jamur dan bakteri.Selain itu, rendahnya keterampilan peneliti saat penanaman juga mempengaruhi tidak terbentuknya tunas.Seperti besar kecilnya potongan eksplan. Semakin besar potongan eksplan maka eksplan tersebut lambat dalam membentuk tunas karena banyak lapisan- lapisan yang menutupi mata tunas sehingga dapat memperlambat terbentuknya tunas.

Hasil pengamatan persentase terbentuknya akar menunjukkan bahwa hanya satu eksplan yang terbentuk akar.Tidak terbentuknya akar disebabkan karena adanya eksplan yang mati, dan adanya eksplan yang belum terbentuk akar.Eksplan yang mati disebabkan karena terkontaminasi oleh jamur dan bakteri.Sedangkan eksplan yang belum berakar disebabkan karena rendahnya konsentrassi IBA yang diberikan pada perlakuan.Semakin tinggi konsentrasi IBA yang diberikan semakin cepat pula eksplan membentuk akar.

Hasil pengamatan jumlah akar menunjukkan bahwa tumbuhnya akar pada perlakuan $i_{5}$ dipengaruhi oleh pemberian hormon IBA dengan konsentrasi 3,5 ppm. Akar yang terbentuk masih kecil.Pemberian hormon IBA dengan konsentrasi tinggi dapat memacu pembentukan akar lebih cepat dan banyak.

Hasil pengamatan jumlah daun menunjukkan bahwa eksplan berdaun terdapat pada perlakuan $i_{3}$ dan $i_{5}$. Perlakuan is memiliki jumlah daun lebih sedikit dibandingkan perlakuan i3.Hal ini disebabkan karena pada perlakuan is konsentrasi IBA lebih tinggi sehingga pertumbuhannya lebih didominasi untuk pembentukan akar. Sedangkan untuk perlakuan $i_{3}$ konsentrasi IBA yang diberikan lebih rendah, sehingga pertumbuhannya lebih didominasi pada pembentukan tunas daun. 
Belum diketahui respon pertumbuhan tanaman nanas pada berbagai konsentrasi IBA dan belum didapat konsentrasi terbaik pada pemberian berbagai konsentrasi IBA terhadap pertumbuhan tanaman nanas secara in vitro.

\section{DAFTAR PUSTAKA}

Dinas Pertanian Tanaman Pangan dan Hortikultura Kabupaten Hulu Sungai Utara. 2014. Data: Luas Tanam, Panen, Rusak dan Produksi Tanaman Buah-buahan dan Sayuran Kabupaten Hulu Sungai Utara (Angka Sementara Kabupaten). Amuntai.

Rukmana, R. 1996. Nenas Budidaya dan Pascapanen. Kanisius. Yogyakarta.

Suprapto, A. 2004. Auksin: Zat Pengatur Tumbuh Penting Meningkatkan Mutu Stek Tanaman. Jurnal UTM. Vol. 21, No. 1. Universitas Tidar Magelang. Http://jurnal.utm.ac.id. Diakses pada tanggal 27-11-2013.

Zulkarnain. 2011. Kultur Jaringan Tanaman. PT Bumi Aksara. Jakarta.

Santoso, U \& F. Nursandi. 2004. Kultur Jaringan Tanaman. UMM Pres. Malang. 